\title{
Cleavages or Mauve Desert as a Post-structuralist Feminist Mystery Novel: Re-covering the "private" investigative subject
}

\author{
Susan McGahan
}

Le désert mauve envisagé comme roman policier poststructuraliste : ou comment traquer le "privé» comme un sujet-enquêteur

$C^{\prime}$ est à une véritable fiction-théorie que Susan McGahan nous convie, à une lecture sur, dans et autour du roman de Nicole Brossard: Le désert mauve. Reprenant à son compte le triptyque structurel du roman, l'auteure nous invite à enquêter sur le réel, à analyser cette écriture qui le traque comme un policier-enquêteur et à partager quelques-unes de ses réflexions théoriques et subjectives qui ont surgi au cours de son travail d'investigation. En fait, le travail de S. McGahan se présente aussi, et c'est tout son plaisir, comme une enquête que chacun ou chacune pourra mener à sa façon et sur le terrain qui l'intéresse: terrain du réel, de l'écriture romanesque ou de l'analyse féministe. Le grand mérite de cette lecture est de retracer, mot à mot, la tentative de Brossard de mettreà jour l'épiphanie mensongère du réel - l'intérieur d'un roman qui lui-même met en jeu les mécanismes du langage, ses trahisons, ses illusions et surtout d'en dévoiler les illusions que les mots fabriquent autour, sur, dans le corps féminin. Il faut donc lire le texte de McGahan comme un jeu de dépistages du réel à travers une recherche policière qui prend les allures d'une enquête langagière.

Notes on the process of creating this body of writing and clues on how to piece the parts together: In this piece the reader is asked to take the position of the investigative subject which means you will have to follow clues that will lead you through the main body of this text and into the /your connecting bodies - (a)part.

The whole corpus, written texts and image/material text (now photographs of), is a triptych as is Mauve Desert: the Pe(e/a)k at your own risk photo montage/shirt/quotes, the textual analysis of Mauve Desert, and in and across/body languages, the poem/prose writing reflections on Mauve Desert. 


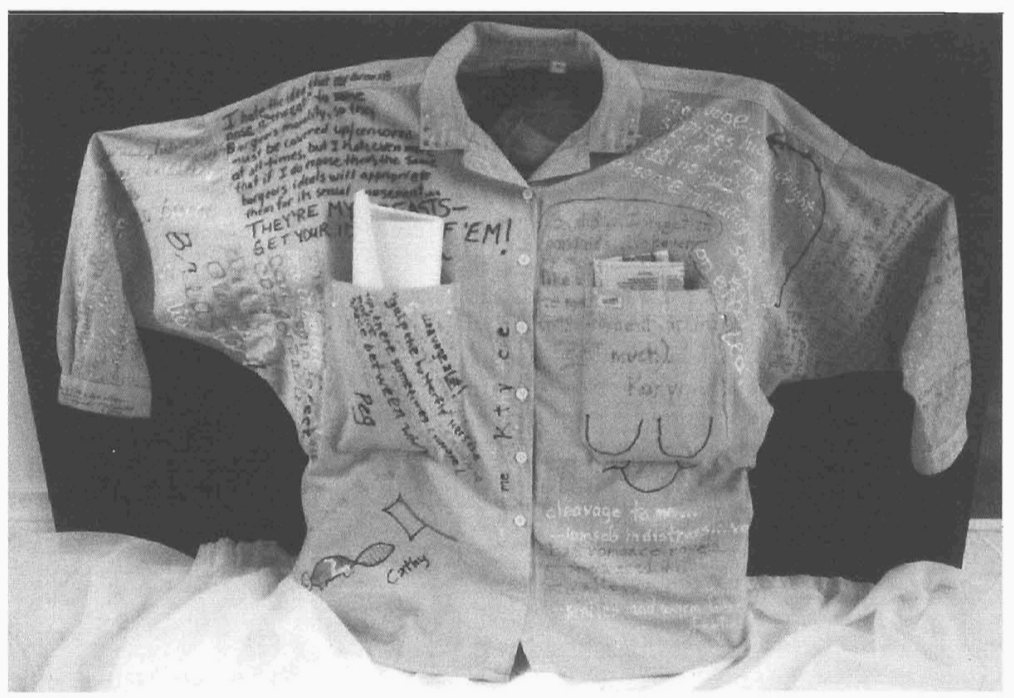


The idea of doing a series of cleavage shots sprang out of a summer afternoon's amusement with the camera and my friend Lorraine. I took most of the shots in the back of a local café (the only café) in Peterborough. Often, we took pictures of each other as a way of negotiating the power associated with the camera. What began as a project strictly on cleavage developed into something else - Breasts! Inspired by the various women's protest marches around the isssue of Bare Breasts, many enthusiastic participants choose not to censor their nipples. Most of all these photos are an expression of women's desire, another medium through which we write the body, a re-appropriation of women's bodies by / for women. (I made doubles so that each participant could admire their own and maybe a friend's!) A celebration of cleavage? Why yes! Each woman wrote reflections on her breasts / cleavage and together we engaged in a process of re/defining which speaks to the dissolution of the overdetermined, uniform male idea(l) of cleavage.

The photo montage plays on Woman as the key to solving mysteries. Note, if you want to solve a mystery - "cherchez la femme"!; both in the post-structuralist sense of the sign of Woman as the condition of possibility, and, in keeping with detective fiction conventions, the line of inquiry often followed by detectives to apprehend Woman because she is (most obviously) the missing piece of the puzzle, or, as Marjorie Garber suggests in her book Vested Interests, "the watchword of the genre of detection" (1992 209). Actually, this all reminds me of a bounty being put on? one's head: "Wanted! Woman. Reward for anyone who has information leading to her whereabouts." (By the way, I am not asking the reader to become a bounty-hunter!) But why are there no heads in these pictures? To reserve the right to anonymity - (mis)apprehensions. It's all very puzzling this business of matching images to text. Good luck! Note in particular cleavages within the text.

Many contemporary feminist writers are challenging gender norms through re/writing highly coded, conventional genres. The number of mystery novels written by women who define themselves as feminists is increasing, which indicates that women writers are beginning to establish feminist detective fiction as an emergent tradition. Within this genre women writers are re/covering Woman from her status as annihilated object of masculine literary pursuits; moving from a representation as an object of investigation to an investigative subject. I, personally, plan on spending my summer reading as many feminist detectives as I can get 
my hot little hands on. I find reading these novels an exciting and stimulating way both to think about feminist political struggles and learn more about ones to which I have not given as much thought. And of course there are all the sexual encounters these P.I. women face. Here, the idea of the investigative subject is also the "private" investigative subject. Moreover, lesbian feminist P.I's not only challenge the private/public dichotomy, but also expose a shift in the political/personal angle of detection within a lesbian context, which, after all, is indicative of lesbian feminist research conducted within the paramaters of a predominately white male heterosexist academic institution. What could Nicole Brossard possibly have to do with feminist mysteries?

Feminist mystery novels cross the boundary between fiction and theory. For feminists, detective fiction becomes a genre through which to debate political issues, involving the reader in a process of re/thinking their own terms or methods of inquiry. For me, the experience of reading detective fiction is critically engaging. Although highly speculative, Nicole Brossard's Mauve Desert lends itself to speculation and thus compels me, as reader of her text, to make some disparate and incongrous connections which play at the level of signification. Thus, in keeping with the terms of Brossard's own writing exploration, I will re/cover her mode of investigation in terms of the mystery novel. First of all, I will explain some conventional expectations of the detective fiction genre. Then I will move into an explanation/exploration of some common themes in feminist detective fictions. Finally, I will engage in a reading of Brossard's Mauve Desert through some of the methods of investigation employed by feminist detectives.

Conventional mysteries are rather conservative in their ideological implications. In a conventional detective fiction a crime takes place within an isolated, bourgeois community which is hierarchical and uncontaminated by outsiders. The crime is considered a breach in a shared morality. There is a closed community of suspects (i.e. the butler). The crime is portrayed as an isolated event, a crime of passion or a moral outrage, that disrupts the status quo. The crime is usually solved by an amateur detective, an established male figure who works virtually single-handedly to analyze the evidence, solve the mystery, expose the criminal and restore the status quo (Coward \& Semple 44). The plot of the conventional detective novel is presented as a simulation of reality which is plausible, but not real. 
Detective plots function as self-reflective paradigms, making the act of reading into one of active producing, interpreting and decoding. However, the narrative demands that the reader follow clues, to de/code the encoded, and the act of reading thus becomes less a matter of interpretation than of producing the "right" reading. Reader and writer both share the universe of fiction-making in language. According to Tzvetan Todorov, the detective novel contains a double narrative: the story of the crime which tells "what really happened" and the story of the investigation which explains "how the reader (or narrator) has come to know about it" (44-45). The second story, Todorov explains, functions to "justify and naturalize" (46) the placing of all the evidence, the facts, within a single privileged discourse. Thus, the reading public enters the private world of detective fiction through a very controlled, hierarchical narrative.

Conventional literary mysteries are based on intellectual intrigue, a game that both the sleuth and the reader try to figure out through a series of logical deductions. "The logical deductions demanded of the reader," says Hutcheon, "place [her/]him... in the shoes of the detective"(1988, 73). The nature of the game for the reader is to try to figure out "whodunnit" before the detective. The reader places herself in the shoes of the detective, follows the investigator's clues to solve the mystery and to eradicate the perpetrator who has disrupted the status quo. The conventional mystery thus interpellates the reader by directly offering the reader a "position from which the text is most 'obviously' intelligible, the position of the subject in (and of) ideology" (Belsey 57).

Feminist re/writings of detective fiction both inscribe and contest the conventional detective fiction genre. In their novels, feminist writers reformulate three central idea(l)s inherent yet concealed within conventional detective fiction: the process of uncovering the crime as a game, the (female) body of (as) evidence, and, as well, the double narrative structure is expanded to account for the narratives' intertextual relation to other discourses and/or texts. Feminists thus rework the genre of detective fiction both to explore the nature of narrative itself and to integrate contemporary feminist issues concerning inscriptions of the female body within patriarchal discourses.

Barbara Godard observes that strategies of intervention employed by female detectives involve "an articulation of their concern with the politics of the detective novel through the textual representation of sexual politics" $(1989,49)$. She calls this phenomenon of re/working the tradi- 
tionally male-defined genre of detective fiction a subgenre which not only questions conventional notions of gender, but also posits an alternative discursive practice which offers a position for female characters to engage in formulating their own subjectivity. In her introduction to her article, "Sleuthing: Feminists Re/writing the Detective Novel," Godard writes:

The border/play characteristic of contemporary women's parodic re/writing of narratives reveals women's engagement with narrative as a critical strategy, designed to expose the positioning of woman as silent other on whose mutilated body the narrative is constructed in dominant discourse and to posit alternate positionings for women as subjects producing themselves in/by language. $(1989,45)$

This strategy articulated by Godard involves a double movement of re/covery: both a recuperation from forced silence and a covering over again, a voicing over. By playing with the conventions and codes of the detective novel, feminist writers thus transform the genre with(in)/by explicit discourses to retrieve the female body from its position of subservience within patriarchal discourses.

Feminist detective fiction accounts for its relation to both previous writings within its genre and current postmodern theorizations of the sign of Woman. These novels do not simply present themselves as autonomous entities, texts with immanent meaning; specific devices are deployed within the text to draw the reader's attention to its textuality (Godard 1989, 47). These textual implications on the part of the writer suggest an inevitable infiltration of both prior and colliding discursive practices and are thus part of the larger phenomenon that has come to be known as intertextuality. The concept of intertextuality, as I understand it, refers to a cultural landscape composed of an infinite system of texts which mingle, circulate, take place, in an arena of texts/genres/mediums/authors/readers that function together to generate meaning. Feminist detective fiction foregrounds its intertextual relations and thus changes the focus of the narrative from the "investigat[ion] of events, to that of investigating the construction of discourses" (Godard 67).

Feminist detective fiction contests the notion of the crime 'enigma' as a game that members of the bourgeois class try to figure out. The themes in these women's novels involve real issues that affect women's lives, not some imaginary game. The sleuth in feminist detective fiction is not endowed with psychologically superior powers that enable her to solve 
the mystery. She continually thinks through the terms of her own inquiry. The female sleuth's method of uncovering the crime is, thus, portrayed as a process involving both the revealing of conventional detective codes and a re-examination of her own approach to the object of her investigation. Traditional vs. feminist lines of inquiry are foregrounded.

In Brossard's poststructural-feminist mystery, the reader can pursue a slightly different turn/angle of re/search. Mauve Desert involves a critique of patriarchy's obsession for an/other/object (i.e. the female body) and, consequently, draws the reader's attention to the discrepancy between readerly and writerly discourse, the difference between interpretation and experience. The main way this is achieved is through Brossard's handling of the theme of the postmodern patriarchal enigma - that is, the textual inscriptions of the female body as a game or a puzzle to solve, or, in other words, the sign of Woman as a site for rhetorical play. In her novel, Brossard utilizes the self-reflective function of the detective genre. She explores the social construction of women's lives, as well as the nature of narrative as a site for the construction of meaning. Brossard questions the gendered inscriptions of the female subject within the genre of conventional detective fiction by investigating the intimate and intricate relations of the social world in which the text is both written and read.

The format of Mauve Desert itself is enigmatic indeed. The desert is a mysterious location or landscape upon which the text(s) circulate. The desert represents both "a[n] historicize[d] site" (Gould 95) recalling the creation of the atomic bomb and the location where the desire for a female community or a separatist female imaginary space is articulated. Mauve Desert is intertextual in construction. It is an assemblage of three separate, yet interrelated texts: Laure Angstelle's originary, uncanonized tale; a transcription of a reader's responses, interpretations, and auto/biographical memos; and Maude Laures' written translation, another overlay of (inter)textual construction (Gould 97). Karen Gould calls Brossard's writing echnique a "tripartite construction," "a threepart presentation generat[ing] a series of probing reflections on the projects of reading, interpreting, and translating the text of another woman"(97). But, "like most of the formal structures and signs in this text," notes Gould,"the desert resists definitions and descriptive containment; it is uninscribable" (95).

The presentation of Brossard's text disrupts many of the conventional expectations a reader brings to the text, particularly those that have to do 
with visual assumptions - the appearance and arrangement of fictionalized narratives/stories. For example, page numbers appear both sequentially at the bottom of the page and divided according to the text's separate parts at the top of the page, so that there are two incongruous numbering systems presented simultaneously on each page. Brossard's divergence from the linear, rational logic of numerics functions to subvert the very notion of a rational decoding of linear narratives and highlights, instead, a reading practice which invites interpretation and speculation. Under the chapter headings of both the original and the translated text, the male figure is given precedence. For Brossard, this seems to indicate that longman is a gross parody of male heroism. Her female characters refuse to write themselves within the traditional categories that chapter headings recall, a form of rejecting the limits or boundaries within which a female protagonist is silenced or negated from the text. Perhaps Brossard is saying that there is no space or place within the highly conventional male-defined genres for a woman to inscribe herself. In any case, what she does is create a new space, a separate site for a female narrator's textual production. She demonstrates through the spatial organization of her text the enunciative exchange between women that exists separate from, but not entirely outside of, masculine imperatives, the inside/outside simultaneity of feminist imaginative space.

There is also a mysterious file folder strategically inserted in the centre of the text, a visual albeit jolting presence/proximity/recollection. This file folder contains a series of photographs of a male figure which appear somewhat anonymous because the images themselves are blurred, especially around the face, which makes identification virtually impossible. The image distortion disturbs conventional photographic captures of the subject; the image refuses to reflect the scopophiliac, voyeuristic male viewer/gaze. Is this Irigaray's "blind spot"? By disrupting the narrative with this visual inscription, Brossard subverts the image of man as a unified, clearly definable subject and she questions photography's place as reputable historical archive. The reader is distanced from and implicated in these visual inscriptions because there is no clearly defined addressee. The relationship between image and text is de-naturalized. The frame refuses to contain what can be characterized as a resemblance. The file folder bears the insignia "Longman" (97), but the images between the folder are depersonalized and the "private eye/I" can no longer discern the guilty suspect. 
This mysterious file folder, which belongs to the realm of political intrigue, is an example of how Brossard problematizes the notion of indication in Mauve Desert. To indicate means to refer to, point to, and make known. For one thing to be indicative of something else suggests a causal relationship between two things, that meaning is somehow obvious or transparent, something one simply uncovers. However, in Brossard's deconstruction of the mystery convention there is a cleavage between the signifier and the signified, between the clue and the crime. The unilinear relationship between the clue and the crime is broken. Unlike the normative conventions of solving mysteries, signifiers no longer refer to particular signifieds. The signifiers or clues to be followed in solving the puzzle or the crime are absent, suggesting that the lack of relationship between the signifier and the signified leaves meaning open to a multiplicity of possible interpretations. Parallelling Lacan's hypothesis, from his famous discussion of Edgar Allen Poe's The Purloined Letter which has both fascinated and titillated post-structural theorists, I am compelled to ask: Does the letter ever reach its destination? Does the clue ever reach the crime? There is no determinable relationship between object and sign, between image and text: there are no markings on the file which would indicate, point to, or refer to a locatable subject to whom the simulacrum belongs. Without a specific designation, the contents of the file folder, the indiscernable male subject, cannot be claimed as private property, as belonging to a specific subject and yet, his ominous presence permeates the daily lives of women. "There is no single signifier attached to a single signified" writes Elizabeth Grosz, "... which marks the absence of a fixed anchoring point." $(1990,95)$. He is what Karen Gould refers to as "a primarily symbolic presence" (99).

In the text-to-be-translated, Laure Angstelle's Mauve Desert, a murder takes place. Following conventional mystery novels, the reader may tend to engage in a process of uncovering the crime, to look for clues to solve the mystery of "whodunit." Laure Angstelle's story ends with an erotic encounter between two women which results in violence, a violence which is both sexual and textual because this moment marks a brutal end to both Angela, the character, and Laure Angstelle's narrative. At the moment of Melanie's physically intense, bodily entanglement with Angela, Angela dies in her arms. She, the narrator tells us, "is dissolving ... lying, there, exposed to all eyes" (46).

From this event springs a serial logical questioning. How 
is Angela's body positioned? Whose gaze is she exposed to? "What happened" (Brossard 46)? And whodunnit? There are a number of possible readings which can be constructed out of the "main event," the physical act of violence directed at the female body. There is Melanie who drives her mother's Meteor across the desert landscape and has an intense desire to make a connection with this woman, Angela, whom she finds sexually intriguing. There are also several references indicating that Melanie does have access to the revolver kept "in the glove compartment" (24) of her mother's car. It could also be an anonymous killer or longman himself who looks on with an "impassive stare" (46). However, the mystery is unsolvable. There is no evidence which can be substantiated to prove who was/is the murderer of Angela Parkins, the mysterious woman who, as Karen Gould notes, is "a mathematician working with a group of male scientists on a top secret project that presumably involves explosive weaponry" (100).

Angela Parkin's body dissolves into the landscape of the desert. Her image disintegrates and is substituted by the image of "Policemen, chalk[ing] around [her] corpse" (46). One image of Angela is transposed onto another: "[ $t]$ he gaze melts" (46). There are no witnesses: no/body "[saw] a thing" (46). Angela's body is surrounded, "chalked" (46) by the policemen. Her corpse is the only body of evidence that indicates a crime has taken place.

Angela's "chalked" body on the road is imaged in terms of a "bloody profile" (46), recalling a bleeding wound - memories or images of bodies imprinted or scarred on pavement during nuclear demonstrations: the shadow images of bodies recalling post-apocalyptical death. The ambiguity of the referent of "memories for digging into in and across/body languages

I feel all encompassed. I want to get out....

of this single snapshot I keep holding up to myself to examine and re-live. Re-enacting memories. I move my body through moments of us over and through pulling out snapshots one and one entering their sanctity, naming my desire, calling out her name.

Assigning words to bodies. Bodies to words. Moving

beyond "I am" to "I desire." Release

these clenching muscles and put

desire down with flesh.

Exposing myself. Am

I over/exposed? Aiming for the perfect angle. The perfect lighting in which to meet her with. Her mouth open. Her tongue extended, pressed right up to the lens. I set the light metre.

Suddenly, she smiles. My fingers falter. i withdraw my hands. the shutter 
words without defiling graves" (46), perhaps a metaphor refering to colonial practices, demonstrates, once again, the slipperiness of meaning in Brossard's text, the difference between meaning and signification. No single meaning can be assigned to Brossard's references. One cannot simply uncover the meaning and solve the mystery as in conventional detective fiction. The ambiguity of the referent opens up the possibility of creating multiple narratives/stories, of which Maude Laures' 'Mauve, the horizon' is just one.

Nevertheless, the body of Angela Parkins is marked as the evidence of violence and disaster; the narrator locates the voyeuristic contemplation of Angela's body in the male gaze. It is the policemen who objectify Angela's body. Her body is the object of their study, the evidence upon which the crime is written. The male figures, the policemen, who are supposedly responsible for enforcing legal codes, focus not on the perpetrator of the crime, but on the female body as evidence of the crime. Her body is rendered an object of aesthetic contemplation, of titillation.

But this moment of male intervention and interpretation of the female body does not enforce closure on the text, nor does it end the investigation into male sexual violence against women. Angela's death marks the beginning of Maude Laures', the female sleuth's, investigation. Maude Laures' inquest into Angela's death leads her into the textual space that Laure Angstelle has formally inhabited. She uses Laure Angstelle's narrative as a basis for her re/construction of the circumstances surrounding Angela's death and enters into a dialogue with the author of the textto-be-translated.

Angela's body is thus both the site of the reinvested imaginary and the site of male appropriation and violence. Only a skeletal outline or shell closes by its own volition. We are frozen here. Still posed. But only for a moment. Our desires defy the frame. Weextend our limbs.

Outstretch our bodies upon a new landscape.

Possibilites.

Pushing other selves

- Manoeuvering the departure - her leaving Making a transition a transposition, a trance position, (trans-position -(de)parting)

transposing the image

The dream translates itself into reality.

Transposed onto precisely what she expected:

A prognosis for a fatal outcome intended to ease the act of dying

images speak of a reality in which the eye did not impute

How differently the pain was felt like a mask of a negative turning inner space inside out bringing corporeality before her eyes 
of her body remains - a trace from which "the desired thing has retreated" (Kamuf 1991:xxxiv). Her body is under erasure. What remains is the residue of desire, the impetus for Maude Laure, the fictional reader's, detection: "Maude Laures is gathering all the clues to her desire" (53).

Mauve Desert foregrounds its own processes of research and exposes the construction of an alternative narrative: Maude Laures' re/writing of Laure Angstelle's text. Maude Laures re/constructs all the different elements of Laure Angstelle's story, including the scenes, the objects and characters that inhabit these places, and, as well, she does a surveillance of the metaphoric landscape, the different perspectives from which Maude approaches her writing. The most interesting of these short vignettes, however, is the dialogue she images between herself and the woman writer, Laure Angstelle. In this dialogue, "the reader-soon-to-become-translator" (Gould 103) cross-examines the woman who wrote Angela Parkin's death sentence(s) and does so by taking on the persona of the assassinated female character herself. Here, the investigation into Angela's death is further probed. However, the dialogue which revolves around trying to pin down evidence that would indicate who exactly is responsible for Angela's death is absurdly displaced and instead focuses on the idea of character assassination. Brossard plays on the ambiguity of meaning by evoking both the literal and the metaphoric sense of the concept of character assassination; the literal killing off of a character and the metaphoric (or colloqual expression) which means to destroy someone's reputation. She articulates this discrepancy in meaning as a negotiation between a woman's life and a man's "fine reputation" (132). Once again, Brossard successfully highlights the futility of uncevering a

\section{AM LOOKING \\ DIFFERENTLY}

Chaos - an exacting graduation of access (Who was allowed to touch and examine her?)

the body emerges from a story of gradual discoveries

Discoveries. (Dis) cover ease

re-defining cleavages finding the le(a)ver(age) in cleavage possibilites for movement into greater spaces (re): story(ing) ourselves....

Our conversations taking turns, rolling off our tongues. Our voices, vigorously richocheting off the hot pavement.

Sometimes there is nothing better than to speak to $a$

dyke

Alandmark.

Your fingers press into myskin

marking a turning point

Or. could it be a landslide?

wafting down one side of a cliff 
single meaning in which to place all other discourses/events.

Angela's body recalls how the female body is inscribed within patriarchal discourses as victim, or as a site of victimization. Lorna, Melanie's mother's lover, however, contests the idea of the female body as a site of victimization and specifically refers to "detective thrillers" (71) as a genre which perpetuates this gendered proscription: "Her anger unrelentingly smashes down on all the male figures disfiguring the gorgeous landscapes she imagines in women's eyes" (71-2). The representation of Woman as victim keeps women powerless and part of Nicole Brossard's political project includes moving women's bodies out of victimization through re/inscribing the female body as a site of resistance and empowerment, from an object of interrogation to an embodied, investigative subject who actively interprets her experiences.

In Mauve Desert Brossard expresses a different approach to her object of investigation. Her investigation is into the letter, the word, the lettered characters by which a writer arranges and elicits meanings: "the letter was a landscape, an enigma entered with each reading" (133). The aim of her investigation is to retrieve the "auther" (other/author/autre) rather than uncover meaning. This re/covery consists of a double movement: both a recuperation or a "time of restoration"(62) and a covering over again of "every word with another in such a way that the first one not sink into oblivion" (61). Through restore(ying) the "private" investigative female subject, Brossard manages not only to shift the meaning of the story written by Laure Angstelle, she also manages to reclaim a female body (of writing) -- textual matter - from obliteration. Immediately prior to the translator's embarcation re: a mass of land sliding down from one side of a cliff

Sometimes I feel I live my life in peril.

Look mom I'm just like you

a third part (y) not possible, you

tell me

about preparations for departure

but don't ever leave

These - hermen

wedged against women in white

There is a woman, I sputter,

Angela - her name

she, too, may never leave the aftermaths of opacity, of white????

How precarious I feel appearing before her straddling a fence waiting for a word she whispers telling all her friends she giggles

Who is he? I ask when she speaks him words become foreign-untranslatable What are my words?!!!!!!!!!!!! 
on her project of re/writing, Brossard evokes the female body as a site of struggle in order to create a new, a "coming to writing" (Gould 35): "[t]he time had come for taking on the book body to body" (161). The female narrator is an active agent in the process of signification. Locating desire in the "lower belly, there where the tongue wants" (161), she reasserts women's power to reposition the body in language.

Although Brossard does not deny that writing is a philosophical/rhetorical game - "[n]ow it would be necessary, in the un-said, to play a close game...words were all Maude Laures could see now" (162), she does refute the idea that it is a game designed merely for intellectual intrigue. Her writing strives to "(re)construct the structures of subjectivity" (Hutcheon 1989, 168) and to (re)imagine desire as an exchange between women.

Maude Laures' translation of Laura Angstelle's text releases the woman "she knows nothing about except the presumed evidence of an existence cloistered in the time and space of a single book" (51). She, the empty sign, the pronominal shifter, escapes the narrative because She resists descriptive containment. She who "resemble[s] a tombstone: a name, a title, and the cover's brightness" (61) leaves traces of a feminine economy of language: a trail of resignifications, a dispersal of clues leading to her whereabouts. Perhaps she is heading towards a preferred direction, splitting off - cleaving herself - from masculine discourses.
(I want to ask-her) constantly speaking in third terms as moments of (im)possiblity impress upon our bodies future sites of struggle

She is wearing another love affair an ensemble in my eyes which you discard like clothing (a scandal amongst neighbours)

imparting a personal meaning

all parts of the body at mercy whether stroked, licked,

savoured, or mourned thick belly pains showing up in a different guise a struggle

visible on the body's surface (t)issues of relief

...some move

to vent the torrent

threads of blood connecting a single life while day to day messages of other cases left their impressions on a landscape

"Of course she had done some investigating, but had uncovered nothing....Everything is still just intention to carry over. Repeated perspective of the two-zvay passage" (57). [Italics added] 
Cleavage...

signifies hidden delight...

but just for me

a real no man's land.

(absence indicating substance)

somewhere

on either side?

- Leah

Oh shit... I forgot my

bandaids...to cover up

my nipples. Looks

like a federal offence

to me.

(any indecent girl knows

THAT much).

- Karyn

The cleavage has always been under-estimated. Who has really understood the value of this site of mediation between 2 unspeakable poles? If the cleavage could speak it would say something like: "between the metonymic points that capture and transfix your gaze sits a mysterious, slight and contentless mediation - to some I am the exchange value of women's unspeakable sexuality, to others, the use value of a lover's touch, between the folds, between the sheets, cover me, recover me, for future warmth, I will not depart - for only (a)partly am I here"

- Julie Lizard

cleavage to me

-damsels in distress...very bad romance novels...

-smothered in...

-valleys...

-smiles and warm fuzzy feelings

- anonymous

Kathy Acker! — Roberta 


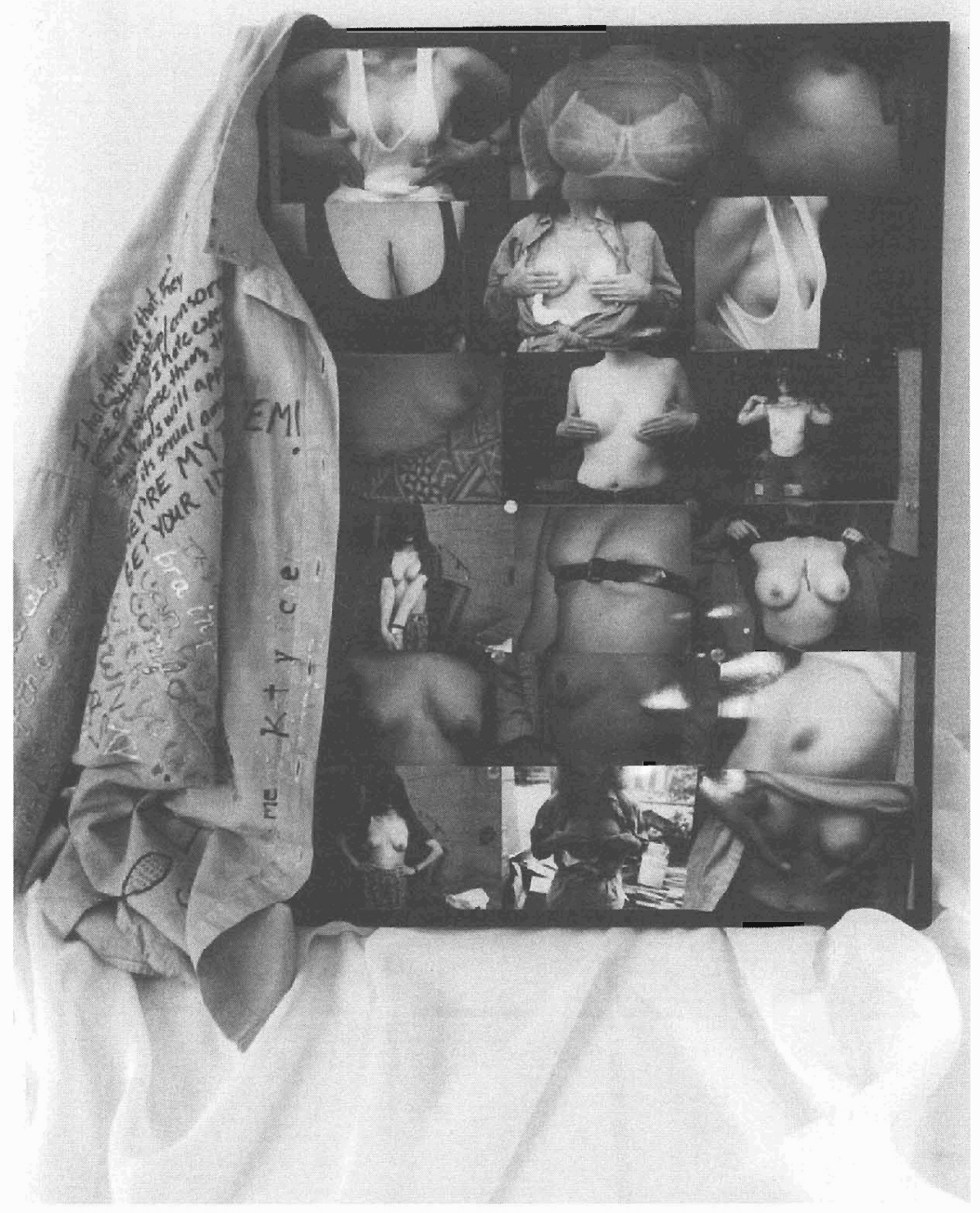




\section{Cleavages $\cdot 117$}

I notice cleavage alot! Sometimes it makes me "bulp the butterfly." Hers is a beach, pebbled and warm. I'm washed up, there sometimes. I suppose I notice mine too.

It's the space between what's beyond.

- Peg

Leave it to Beaver Clever. - Cathy

It's only in not wearing a bra in public that you can begin to feel comfortable with your own breasts! — Sadie

Cleavage - beauty, lust, natural, human re-made - all part of the essence of woman. Having lost breasts, it feels reassuring, enlivening to have them again. - anonymous

Special thanks to all the women who posed for the photos and to Julia Emberley, Sharon Rosenberg and Charmaine Eddy for their enthusiasm and support. Thanks to Lisa Bader for help with the photos.

\section{Works Cited}

Belsey, Catherine. Critical Practice. New York: Methuen, 1980. Brossard, Nicole. Mauve Desert. Trans. Susanne de Lotbinière-

Harwood. Toronto: Coach House Press, 1990. Originally published Le Desert Mauve, editions de l'Hexagone, Montreal,1987.

Coward, Rosalind \& Semple, Linda. 'Trackin down the past: women and detective fiction' in From My Guy to Sci-fi: Genre and Women's Writing in the Postmodern World. Ed. Helen Carr. London: Pandora Press, 1989.

Garber, Marjorie. Vested Interests: Cross-Dressing and Cultural Anxiety. New York: Routledge, 1992.

Godard, Barbara, 'Sleuthing: Feminists Re/writing the Detective Novel' in Signature 1 (Summer 1989): 45-70

Gould, Karen. Writing in the Feminine: Feminism and Experimental

Writing in Quebec. Carbondale and Edwardsville: Southern Illinois University Press, 1990. 
Grosz, Elizabeth, Jacques Lacan: A Feminist Introduction. New York: Routledge, 1990.

Hutcheon, Linda. Narcissistic Narrative: the Metafictional Paradox. New York: Meuthen, 1988. 1989.

Kamuf, Peggy, ed. A Derrida Reader: Between the Blinds. New York: Columbia University Press, 1991.

Todorov, Tzvetan. The Poetics of Prose. Trans. Richard Howard. Ithaca: Cornell University Press, 1977. 